\title{
Growth and Yield Response of Garlic Genotypes to Foliar Application of $\gamma$-Aminobutyric Acid
}

\author{
Eltohamy A. A. Yousef and Ibrahim N. Nasef \\ Department of Horticulture, Faculty of Agriculture, Suez Canal University, Ismailia, Egypt.
}

Received: $7 / 1 / 2019$

\begin{abstract}
Worldwide, garlic is one of the most important bulb vegetable crops and it has been cultivated from thousands of years ago due to its medicinal and nutritional benefits. The main goal of the current research was to explore the effect foliar application of $\gamma$-aminobutyric acid (GABA) on vegetative development and yield traits as well as chemical constitutes of garlic. To achieve this goal, two field experiments were performed during winter seasons of 2015/2016 and 2016/2017. Four concentrations of GABA (0,1, 2 and $4 \mathrm{mM}$ ) were sprayed on two garlic's genotypes (Sids 40 and Egaseed). The results reported that exogenous supplementation of GABA notably improved vegetative growth (plant height and plant fresh weight), yield traits (bulb weight and total yield), and minerals content ( $\mathrm{N}, \mathrm{P}, \mathrm{K}$ and $\mathrm{Ca}$ ), as well as the content of organic compounds (total chlorophyll and total phenols) compared to non-treated plants (control) in both genotypes. It was clearly revealed that $1 \mathrm{mM} \mathrm{GABA}$ treatment had achieved the highest morphological traits, yield traits, chemical composition and organic compound content compared to the other GABA treatments. The findings indicate that GABA application has the ability to enhance growth and productivity of garlic through enhancing mineral composition and organic compounds.
\end{abstract}

Keywords: Allium sativum L., GABA, Vegetative growth, Mineral composition

\section{INTRODUCTION}

Garlic (Allium sativum L.) is a principal member of Alliaceae family. Due to its nutritional and medicinal benefits, garlic is considered to be an important ingredient in the daily diet over the world. Garlic has an important compound known as allicin, which has therapeutic properties. Consequently, garlic is well known for its ability to work as a natural antimicrobial. Also, it contributes positively to human health as anti-cancer, antidiabetic, antimicrobial, antiinflammatory, immunomodulatory properties, cardio protective and antioxidant (Kumar et al., 2013; Chen et al., 2013; Yun et al., 2014; Martins et al., 2016). World total production of garlic was approximately 27 million tons that were produced from 179534 hectares (FAO, 2016). Egypt is ranked fourth in worldwide garlic production, with an annual production of 280,216 tons from around 11,875 hectares (FAO, 2016). In addition, Egypt is one of the top 10 countries that exported the highest dollar value worth of garlic in 2017 with $0.9 \%$ (27 million dollars) of total garlic exports. However, the garlic production in Egypt dramatically fluctuated in last ten years (FAO, 2016). Therefore, getting high yield rather than stable yield is necessary aims for garlic's growers as it is an important crop for local consumption and export.

Several chemicals were introduced to improve the agricultural productivity under favorable and unfavorable environments. One of these promising chemicals is called $\gamma$-aminobutyric acid (GABA). It is a four-carbon non-protein amino acid that is generally exists in both animal and plant tissues. It is found in the central nervous system tissues of mammals (Sigel and Steinmann, 2012). Briefly, GABA is resulted from glutamic acid decarboxylation or polyamine degradation (Yang et al., 2013; Ford et al., 1996) and is basically metabolized through a direct pathway consists of three enzymes. Numerous studies have confirmed a positive effect for GABA intake on human health, including decreasing the blood pressure, inhibition cancer cell multiplying, energizing cancer cell apoptosis (Oh and Oh, 2004). Therefore, several attempts were performed out to increase endogenous GABA content in local daily-consumed foods (Nonaka et al., 2017).

In the last few years, the interest in GABA use in plant was increased. Interestingly, several previous studies confirmed the positive results of exogenous GABA application in plants. It is commonly demonstrated that exogenous supplementation of GABA is taking a part in several physiological mechanisms, consequently it causes an improvement in morphological, growth and yield attributes of plants. Once plants encounter abiotic or biotic stress they directly accumulate high amount of GABA (Shelp et $a l ., 2012)$. This accumulation has been shown to take a part in several important physiological processes in plants. In this regard, it was reported that GABA external supplementation positively improved the drought tolerance in perennial ryegrass and creeping bentgrass, black pepper and black cumin (Krishnan et al., 2013; Vijayakumari and Puthur, 2015; Li et al., 2018; Rezaei-Chiyaneh et al., 2018). Also, it was clearly documented that GABA treatment play a key role in attenuation of damage induced by salt stress in several crop species such, as tomato, melon, wheat and maize (Xiang et al., 2016; Li et al., 2016a; Wang et al., 2017; Cekiç, 2018). In addition, GABA was able to increase winter wheat tolerance to high temperature and had the ability to alleviate the low light stress in pepper seedlings (Wang et al., 2009; Li et al., 2017)

Mechanism of GABA in alleviation the harmful effects resulting from the abiotic stresses depends on plant species and abiotic stress type. However, this mechanism may be due to one or more of these physiological effects: 1) Enhancing water soluble 
carbohydrates, proline accumulation, total sugars content, chlorophyll content, phenolic substances, photosynthetic capacity, enzyme activities, relative water content and membrane stability, chloroplast structure, as well as function of PSII, level of photochemical efficiency (Krishnan et al., 2013; Vijayakumari and Puthur 2016; Li et al. 2017; RezaeiChiyaneh et al., 2018). 2) Decreasing malondialdehyde content, electrolyte conductivity, lipid peroxidation and active oxygen species (Xiang et al., 2016; Li et al., 2016a; Wang et al., 2017; Cekiç, 2018). 3) Regulating endogenous hormone system (Wang et al., 2009)

GABA has also several positive effects during fruit and vegetable storage. For instance, it was apparently declared that GABA application is a helpful tool in reduction of chilling injury during cold-storage in peach and banana fruits through acceleration of endogenous GABA content, proline accumulation and antioxidant system (Shang et al., 2011; Wang et al., 2014). In addition, GABA plays an important role in reducing the browning of fresh-cut potatoes through enhancing the catalase and superoxide dismutase activities, as well as decreasing the polyphenol oxidase activity and reactive oxygen species (Gao et al., 2018). Moreover, GABA has a favorable impacts on unstressed plants, including enhancement of vase-life of rose cut flowers (Mirzaei Mashhoud et al., 2015), increasing growth of citrus plants (Hijaz et al., 2018), enhancement early growth and photosynthesis traits in maize seedlings.

In consonance with the above-mentioned information, the application of GABA can enhance agricultural productivity of several of horticultural crops under favorable condition and under different kinds of abiotic stresses through several physiological processes. So far, little comprehensive information is available about the effect of exogenous GABA treatment on garlic's growth, productivity and quality. Accordingly, goal of this study was to investigate the physiological effects of GABA supplementation on traits of vegetative growth, yield parameters and on chemical composition of garlic under normal conditions.

\section{MATERIALS AND METHODS}

\section{Plant materials and treatments}

Two field experiments were carried out in winter seasons of 2015/2016 and 2016/2017 at Research Experimental field of the Faculty of Agriculture, Suez Canal University, Ismailia, Egypt to study the effect of four concentrations of $\operatorname{GABA}(0,1$, 2 and $4 \mathrm{mM}$ ) on vegetative growth, yield and chemical composition of two of the most garlic's genotypes in Egypt (Sids 40 and Egaseed). The experimental design for the two field experiments was randomized complete blocks design (RCBD) with a split plot arrangement with three replicates. The genotypes were assigned in the main plots, while GABA levels were assigned in the sub-plots.

Soil texture was sandy (85.21\% sand, 3.29\% clay and $11.50 \%$ silt), with $\mathrm{pH} 7.87$, EC $0.47 \mathrm{dSm}^{-1}$, available N 63 ppm, available P 29.24 ppm, available K 74 ppm, $\mathrm{Ca}^{+2} 1.7 \mathrm{meql}^{-1}, \mathrm{Mg}^{+2} 0.8 \mathrm{meql}^{-1}, \mathrm{Na}^{+} 0.9$ $\mathrm{meql}^{-1}, \mathrm{~K}^{+} 0.2 \mathrm{meql}^{-1}, \mathrm{HCO}_{3}^{-} 1.60 \mathrm{meql}^{-1}, \mathrm{Cl}^{-} 1.40$ $\mathrm{meql}^{-1}$ and $\mathrm{SO}_{4}{ }^{-2} 0.60 \mathrm{meql}^{-1}$ and $\mathrm{CO}_{3}^{-2} 0.00 \mathrm{meql}^{-1}$ organic matter $0.15 \%$, organic carbon $0.083 \%$.

After soil clearing, ploughing and harrowing, organic manure and superphosphate $\left(\begin{array}{lll}15.5 \% & \mathrm{P}_{2} \mathrm{O}_{5}\end{array}\right)$ were added at $20 \mathrm{~m}^{3} / \mathrm{fad}$ and $150 \mathrm{~kg} / \mathrm{fed}$, respectively. Later, drip irrigation system was used. Uniform and healthy cloves of both genotypes were selected and soaked in running water for $24 \mathrm{~h}$. In the next day, the wetted cloves were sown by hands at $10 \mathrm{~cm}$ between the plants and $100 \mathrm{~cm}$ between the rows. The planting was performed on 15 of October in both seasons. Experimental unit area (plot) was $3 \mathrm{~m} \times 3 \mathrm{~m}$ in size (three rows).

The GABA treatments were given to the plants five times through the whole season on the whole foliage in the morning (10 a.m.) with a manual pump. The plants of both genotypes received the first GABA treatment after one month from planting date and with 2 weeks intervals. The control plants of both genotypes were sprayed with only distilled water. The volume of treatments solution was ranged from 156 to $468 \mathrm{~L}$ per Feddan each time, according to plant size. The other normal agricultural treatments were performed according to recommendation of Ministry of Agriculture.

\section{Vegetative growth and yield parameters}

Ten mature plants, when older leaves turned yellowish green and started withering, were harvested (end of March) from each replicate to measure the following parameters:

- Plant height (cm).

- Plant fresh weight (g).

- Bulb fresh weight (g): It was estimated after removing the foliage at neck zone.

- Bulbing ratio: It was estimated according to the formula described by Mann, (1952) as follow: Bulbing ratio $=$ (bulb neck diameter $(\mathrm{cm}) / \mathrm{bulb}$ diameter $(\mathrm{cm}))$. Both bulb diameter and neck diameter were measured using a precision caliper 0/0001 m.

- Roundness: It was calculated by dividing the bulb length/bulb width. Both of bulb length and bulb width were measured using a precision caliper $0 / 0001 \mathrm{~m}$.

\section{Total Yield}

Total yield (Kg/Feddan): Plants of each experimental plot were harvested after 180 days from sowing, weighted and total yield of whole plants was calculated.

\section{Chemical composition parameters \\ Organic compounds}

The chlorophyll content (SPAD value) in the leaf samples was assessed by a SPAD-502 meter (Minolta Co. Ltd., Osaka, Japan).

- Total phenols (mg/g FW) were determined according to Mazumdar and Majumder, (2003). 
- Total sugars (mg/g FW) were determined according to Dubois et al. (1956).

- Soluble solid content (SSC, \%) was measured by a digital refractometer (Atago N1, Japan).

\section{Minerals determination}

Two bulbs from each replicate were dried at $70^{\circ} \mathrm{C}$ till constant weight. Later, they were grounded into powder. $0.5 \mathrm{~g}$ of fine ground materials was digested with sulfuric acid and hydrogen peroxide mixture and then with distilled water the final volume was adjusted to $100 \mathrm{ml}$ with for determination of the following elements:

- Total nitrogen (mg/g DW): it was measured using semi-micro-kjeldahl method as described by Ling (1963).

- Phosphorus (mg/g DW): it was analyzed as described by Jackson (1973).

- Potassium and calcium (mg/g DW): they were determined using a Perkin-elmer, Flame photometer (Page, 1982).

\section{Statistical analysis}

All statistical procedures including analysis of variance (ANOVA) and Duncan's test for that collected data was performed out using CoStat version 6.303 1998-2004 CoHort software, 798 Lighthouse Ave, PMP 320, Monterey, CA 93940, USA. Duncan's test was applied at $1 \%$ significance level to compare the means of treatments.

\section{RESULTS \\ Effect of GABA on vegetative growth, bulb and yield traits}

Table (1) shows the main effect of genotype, GABA and their interaction on vegetative growth and yield traits. The results demonstrated that there was a highly significant difference between the two genotypes for most of the studied traits in both seasons, except roundness trait as well as bulbing ratio and total yield in 2016/2017 season. Egaseed cultivar achieved the highest values compared to Sids 40 for all studied traits (Table 1). The main effect of GABA significantly affected growth, bulb and yield traits. GABA treatments clearly achieved higher plant growth, bulbing and yield compared to control plants in both genotypes and seasons, except roundness trait. Among GABA treatments, the treatment at $1 \mathrm{mM}$ GABA, followed by 2 $\mathrm{mM}$ GABA, was more efficient than the remaining GABA levels: $4 \mathrm{mM}$ GABA and the $0 \mathrm{mM}$ GABA (control). The treatment by $4 \mathrm{mM}$ also positively improved the studied traits; however, this improvement was not necessarily significant. Inconsiderable effect of GABA application was recorded for the roundness trait in both genotypes and seasons. In 2015/2016 season, the foliar spray by $1 \mathrm{mM}$ GABA improved the bulb weight and total yield by $30.01 \%$ and $27.29 \%$ over the two genotypes, respectively. In season of 2016/2017, it improved the bulb weight and total yield by $29.63 \%$ and $30.00 \%$ over the two genotypes, respectively. In addition, Table (1) shows the interaction effects between genotype and GABA treatments. It shows that Egaseed plants that were sprayed with $1 \mathrm{mM}$ GABA had the highest plant growth, bulb and yield traits compared to other combinations. The exogenous application of GABA at $1 \mathrm{mM}$ to Egaseeds plants increased bulb weight and total yield of Egaseeds cultivar by $37.27 \%$ and $24.50 \%$, respectively, over the two growing seasons.

\section{Effect of GABA on SSC, total chlorophyll, total sugars and total phenols}

Table (2) shows the main effects of genotype, GABA treatments and their interaction on SSC, total chlorophyll content, total sugars and total phenols. It shows that there was a significant difference between the two genotypes for all traits, except SSC content in 2015/2016 season. Egaseed had the highest SSC, total chlorophyll, total sugars and total phenols in both seasons. There were significant differences among GABA treatments in Table (2). The highest total chlorophyll and total phenol content were observed in plants treated by $1 \mathrm{mM}$ and $2 \mathrm{mM}$ GABA in both genotypes and seasons. The exogenous application by $1 \mathrm{~mm}$ GABA increased total chlorophyll and total phenol content by $13.90 \%$ and $72.62 \%$ over the both genotypes and seasons. In contrast to the previous results, these treatments significantly decreased both SSC and total sugars compared to non-treated plants in both genotypes and seasons. The foliar application by 1 Mm decreased total SSC and total sugars content by $5.36 \%$ and $26.88 \%$ over the both genotypes and seasons. Interestingly, the exogenous application by 4 $\mathrm{mM}$ did not dramatically increase or decrease the studied traits in comparison to the control plants. Regarding the interaction effect between genotype and GABA treatments, the results revealed that Egaseed plants sprayed with $1 \mathrm{mM}$ and $2 \mathrm{mM}$ GABA had the highest chlorophyll content and total phenols in comparison with other combinations.

\section{Effect of GABA on mineral content.}

Table (3) shows the main effects of genotype, GABA treatments and their interaction on mineral content: $\mathrm{N}, \mathrm{P}, \mathrm{K}$ and $\mathrm{Ca}$. It shows that there were significant differences between the genotypes in both seasons for all studied traits, except phosphorus content in season 2016/2017. The results indicated that Egaseed cultivar had the significant highest nitrogen, phosphorus, potassium and calcium content in both seasons. Concerning the main effect of GABA treatments overall genotypes, there were highly significant differences among GABA treatments. It clearly indicates that four GABA concentrations positively improved nitrogen, phosphorus, potassium and calcium content in both seasons compared to un-treated plants. However, the application of GABA at $1 \mathrm{mM}$ gave the highest nitrogen, phosphorus, potassium and calcium in both seasons compared to the other GABA treatments. In addition, Table (3) shows the interaction effects between genotype and GABA treatments. It shows doubtless that the combination of Egaseed and GABA $1 \mathrm{mM}$ recorded the significant highest nitrogen, phosphorus, potassium and calcium in both seasons. This combination was flowed by the combination of Egaseed and $2 \mathrm{mM}$ GABA in season 2015/2016. However, the best combination was followed by another combination (Sids 40 and $1 \mathrm{mM}$ ) in season of 2016/2017. 
Table (1): Main effects of genotype, GABA treatment and their interactions on vegetative growth and yield traits of garlic during 2015/2016 and 2016/2017 seasons

\begin{tabular}{|c|c|c|c|c|c|c|c|}
\hline \multirow{3}{*}{ Parameters } & \multirow{3}{*}{ GABA } & \multicolumn{3}{|c|}{ 2015-2016 } & \multicolumn{2}{|r|}{ 2016-2017 } & \multirow{3}{*}{ Mean } \\
\hline & & \multicolumn{2}{|c|}{ Genotype } & \multirow{2}{*}{ Mean } & \multicolumn{2}{|c|}{ Genotype } & \\
\hline & & Egaseed & Sids 40 & & Egaseed & Sids 40 & \\
\hline \multirow{5}{*}{$\begin{array}{l}\text { Plant height } \\
(\mathrm{cm})\end{array}$} & $0 \mathrm{mM}$ & $49.40 \mathrm{~d}$ & $43.80 \mathrm{e}$ & 46.60D & $54.80 \mathrm{bcd}$ & 49.30D & $52.05 \mathrm{C}$ \\
\hline & $1 \mathrm{mM}$ & $65.60 \mathrm{a}$ & $62.60 \mathrm{~b}$ & $64.10 \mathrm{~A}$ & $61.20 \mathrm{a}$ & $55.80 \mathrm{ABC}$ & $58.50 \mathrm{~A}$ \\
\hline & $2 \mathrm{mM}$ & $61.00 \mathrm{~b}$ & $54.80 \mathrm{c}$ & 57.90B & $57.90 \mathrm{ab}$ & $54.00 \mathrm{BCD}$ & $55.95 \mathrm{AB}$ \\
\hline & $4 \mathrm{mM}$ & $50.50 \mathrm{~d}$ & $48.20 \mathrm{~d}$ & 49.35C & $51.30 \mathrm{~cd}$ & $53.50 \mathrm{BCD}$ & $52.40 B C$ \\
\hline & Mean & $56.63 \mathrm{~A}$ & 52.35B & & $56.30 \mathrm{~A}$ & 53.15B & \\
\hline \multirow{5}{*}{$\begin{array}{l}\text { Fresh weight } \\
\text { (g/plant) }\end{array}$} & $0 \mathrm{mM}$ & $79.40 \mathrm{e}$ & $72.20 \mathrm{f}$ & $75.80 \mathrm{D}$ & $83.90 \mathrm{c}$ & $77.30 \mathrm{~d}$ & $80.60 \mathrm{C}$ \\
\hline & $1 \mathrm{mM}$ & $111.20 \mathrm{a}$ & $101.10 \mathrm{~b}$ & $106.15 \mathrm{~A}$ & $106.30 \mathrm{a}$ & $102.80 \mathrm{a}$ & $104.55 \mathrm{~A}$ \\
\hline & $2 \mathrm{mM}$ & $91.50 \mathrm{c}$ & $94.90 \mathrm{c}$ & 93.20B & $102.40 \mathrm{a}$ & $96.50 \mathrm{~b}$ & 99.45B \\
\hline & $4 \mathrm{mM}$ & $80.70 \mathrm{de}$ & $84.10 \mathrm{~d}$ & $82.40 \mathrm{C}$ & $85.30 \mathrm{c}$ & $82.30 \mathrm{c}$ & 83.80C \\
\hline & Mean & $90.70 A$ & 88.08B & & $94.48 \mathrm{~A}$ & 89.73B & \\
\hline \multirow{5}{*}{$\begin{array}{l}\text { Bulb weight } \\
\text { (g/Bulb) }\end{array}$} & $0 \mathrm{mM}$ & $60.40 \mathrm{~d}$ & $55.20 \mathrm{e}$ & $57.80 \mathrm{C}$ & $49.30 \mathrm{e}$ & $65.10 \mathrm{c}$ & $57.20 \mathrm{C}$ \\
\hline & $1 \mathrm{mM}$ & $79.00 \mathrm{a}$ & $71.30 \mathrm{~b}$ & $75.15 A$ & $70.10 \mathrm{~b}$ & $78.20 \mathrm{a}$ & $74.15 \mathrm{~A}$ \\
\hline & $2 \mathrm{mM}$ & $66.30 \mathrm{c}$ & $65.90 \mathrm{c}$ & $66.10 \mathrm{~B}$ & $64.90 \mathrm{c}$ & $76.70 \mathrm{a}$ & $70.80 \mathrm{~B}$ \\
\hline & $4 \mathrm{mM}$ & $64.60 \mathrm{~cd}$ & $62.20 \mathrm{~cd}$ & $63.40 \mathrm{~B}$ & $54.30 \mathrm{~d}$ & $64.20 \mathrm{c}$ & $59.25 \mathrm{C}$ \\
\hline & Mean & 67.57A & $63.65 B$ & & $71.05 \mathrm{~A}$ & 59.65B & \\
\hline \multirow{5}{*}{ Bulbing ratio } & $0 \mathrm{mM}$ & $0.22 b c$ & $0.17 \mathrm{~d}$ & $0.19 B$ & $0.20 \mathrm{~b}$ & $0.19 b$ & $0.19 B$ \\
\hline & $1 \mathrm{mM}$ & $0.27 \mathrm{a}$ & $0.24 \mathrm{ab}$ & $0.26 \mathrm{~A}$ & $0.28 \mathrm{a}$ & $0.27 \mathrm{a}$ & $0.28 \mathrm{~A}$ \\
\hline & $2 \mathrm{mM}$ & $0.25 \mathrm{ab}$ & $0.24 \mathrm{ab}$ & $0.24 B$ & $0.27 \mathrm{a}$ & $0.25 \mathrm{a}$ & $0.26 \mathrm{~A}$ \\
\hline & $4 \mathrm{mM}$ & $0.22 b c$ & $0.19 \mathrm{~cd}$ & $0.21 B$ & $0.22 b$ & $0.21 b$ & $0.21 B$ \\
\hline & Mean & $0.24 \mathrm{~A}$ & $0.21 B$ & & $0.24 \mathrm{~A}$ & $0.23 \mathrm{~A}$ & \\
\hline \multirow{5}{*}{ Roundness } & $0 \mathrm{mM}$ & $0.91 \mathrm{a}$ & $0.86 a$ & $0.89 \mathrm{~A}$ & $0.95 \mathrm{a}$ & $0.85 \mathrm{a}$ & $0.90 \mathrm{~A}$ \\
\hline & $1 \mathrm{mM}$ & $0.89 a$ & $0.84 \mathrm{a}$ & $0.86 \mathrm{~A}$ & $0.87 \mathrm{a}$ & $0.81 \mathrm{a}$ & $0.84 \mathrm{~A}$ \\
\hline & $2 \mathrm{mM}$ & $0.90 \mathrm{a}$ & $0.84 \mathrm{a}$ & $0.87 A$ & $0.85 \mathrm{a}$ & $0.84 \mathrm{a}$ & $0.85 \mathrm{~A}$ \\
\hline & $4 \mathrm{mM}$ & $0.93 \mathrm{a}$ & $0.84 \mathrm{a}$ & $0.88 \mathrm{~A}$ & $0.89 \mathrm{a}$ & $0.82 \mathrm{a}$ & $0.86 A$ \\
\hline & Mean & $0.91 \mathrm{~A}$ & $0.84 \mathrm{~A}$ & & $0.89 A$ & $0.83 \mathrm{~A}$ & \\
\hline \multirow{5}{*}{$\begin{array}{l}\text { Total } \\
\text { (kg/Fed) }\end{array}$} & $0 \mathrm{mM}$ & 4832 de & $4315 f$ & 4573.5C & $5208 c$ & $3944 \mathrm{e}$ & $4576 \mathrm{C}$ \\
\hline & $1 \mathrm{mM}$ & $6320 \mathrm{a}$ & $5322 \mathrm{c}$ & 5821.0A & $6256 a$ & $5608 \mathrm{~b}$ & 5932A \\
\hline & $2 \mathrm{mM}$ & $5850 \mathrm{~b}$ & $5372 \mathrm{c}$ & $5611.0 A$ & $6136 a$ & $5192 c$ & $5664 B$ \\
\hline & $4 \mathrm{mM}$ & $5168 \mathrm{~cd}$ & $4573 \mathrm{ef}$ & 4870.5B & $5136 c$ & $4344 d$ & 4740C \\
\hline & Mean & $5542.50 \mathrm{~A}$ & 4895.50B & & $5684.00 A$ & 4772.00A & \\
\hline
\end{tabular}

Values are the means of three replicates. Values followed by the same letters within a column for each genus are not significantly different at the $1 \%$ level of probability according to Duncan's multiple range test 
Table (2): Main effects of genotype, GABA treatment and their interactions on SSC, total cholorphyll, total sugars and total phenols of garlic

\begin{tabular}{|c|c|c|c|c|c|c|c|}
\hline \multirow{3}{*}{ Parameters } & \multirow{3}{*}{ GABA } & \multirow{2}{*}{\multicolumn{2}{|c|}{$\begin{array}{l}\text { 2015-2016 } \\
\text { Genotype }\end{array}$}} & \multicolumn{3}{|c|}{ 2016-2017 } & \multirow{3}{*}{ Mean } \\
\hline & & & & \multirow{2}{*}{ Mean } & \multicolumn{2}{|l|}{ Genotype } & \\
\hline & & Egaseed & Sids 40 & & Egaseed & Sids 40 & \\
\hline \multirow{5}{*}{ SSC \% } & $0 \mathrm{mM}$ & $40.20 \mathrm{ab}$ & $40.80 \mathrm{ab}$ & $40.50 \mathrm{~A}$ & $42.00 \mathrm{a}$ & $40.70 \mathrm{abc}$ & $41.35 A$ \\
\hline & $1 \mathrm{mM}$ & $36.10 \mathrm{~d}$ & $39.60 \mathrm{abc}$ & 37.85B & $39.30 \mathrm{bc}$ & $39.90 \mathrm{abc}$ & 39.60B \\
\hline & $2 \mathrm{mM}$ & $37.55 \mathrm{~cd}$ & $38.80 \mathrm{bc}$ & 38.18B & $40.20 \mathrm{abc}$ & $38.80 \mathrm{c}$ & $36.50 \mathrm{~B}$ \\
\hline & $4 \mathrm{mM}$ & $41.80 \mathrm{a}$ & $39.40 \mathrm{abc}$ & $40.60 \mathrm{~A}$ & $41.40 \mathrm{ab}$ & $39.30 \mathrm{bc}$ & 40.35AB \\
\hline & Mean & 39.91A & $39.65 \mathrm{~A}$ & & 40.73A & 39.68B & \\
\hline \multirow{5}{*}{$\begin{array}{l}\text { Total } \\
\text { Chlorophyll } \\
\text { (SPAD value) }\end{array}$} & $0 \mathrm{mM}$ & $54.80 \mathrm{~b}$ & $46.30 c$ & $50.55 C$ & $56.70 \mathrm{c}$ & $48.50 \mathrm{e}$ & $52.60 \mathrm{C}$ \\
\hline & $1 \mathrm{mM}$ & $70.60 \mathrm{a}$ & $58.60 \mathrm{~b}$ & $64.60 \mathrm{~A}$ & $65.20 \mathrm{a}$ & $61.50 \mathrm{ab}$ & 63.35A \\
\hline & $2 \mathrm{mM}$ & $58.70 \mathrm{~b}$ & $52.90 \mathrm{~b}$ & 55.80B & $62.80 \mathrm{a}$ & $53.60 \mathrm{~cd}$ & 58.20B \\
\hline & $4 \mathrm{mM}$ & $56.50 \mathrm{~b}$ & $47.00 \mathrm{c}$ & $51.75 \mathrm{C}$ & $58.00 \mathrm{bc}$ & 49.40de & $53.70 \mathrm{C}$ \\
\hline & Mean & $60.15 A$ & 51.20B & & $60.68 \mathrm{~A}$ & 53.26B & \\
\hline \multirow{5}{*}{$\begin{array}{l}\text { Total Sugars } \\
(\mathrm{mg} / \mathrm{g} \text { FW) }\end{array}$} & $0 \mathrm{mM}$ & $200.02 a$ & $176.63 b$ & $188.32 \mathrm{~A}$ & $176.63 a$ & $185.02 \mathrm{a}$ & $180.83 A$ \\
\hline & $1 \mathrm{mM}$ & $148.89 \mathrm{c}$ & $133.66 \mathrm{de}$ & 141.27B & $138.66 \mathrm{c}$ & $118.89 \mathrm{~d}$ & $128.77 \mathrm{C}$ \\
\hline & $2 \mathrm{mM}$ & $150.69 \mathrm{c}$ & $143.42 \mathrm{~cd}$ & 147.06B & $131.61 \mathrm{~cd}$ & $125.69 \mathrm{~cd}$ & $128.65 C$ \\
\hline & $4 \mathrm{mM}$ & $168.22 b$ & $131.60 \mathrm{e}$ & 149.91B & $158.43 b$ & $133.22 \mathrm{~cd}$ & 145.82B \\
\hline & Mean & $166.95 \mathrm{~A}$ & $146.33 \mathrm{~B}$ & & 151.32A & $140.71 B$ & \\
\hline \multirow{5}{*}{$\begin{array}{l}\text { Total phenols } \\
(\mathrm{mg} / 100 \mathrm{~g} \text { FW) }\end{array}$} & $0 \mathrm{mM}$ & $23.92 c$ & $14.41 \mathrm{~d}$ & $19.16 \mathrm{C}$ & $19.92 \mathrm{de}$ & $14.41 \mathrm{f}$ & $17.17 \mathrm{C}$ \\
\hline & $1 \mathrm{mM}$ & $33.22 \mathrm{a}$ & $31.96 \mathrm{a}$ & 32.59A & $28.22 \mathrm{ab}$ & $31.96 \mathrm{a}$ & 30.09A \\
\hline & $2 \mathrm{mM}$ & $29.02 \mathrm{ab}$ & $27.11 b c$ & 28.07B & $24.02 \mathrm{bcd}$ & $23.11 \mathrm{~cd}$ & 23.57B \\
\hline & $4 \mathrm{mM}$ & $24.59 \mathrm{bc}$ & $16.63 \mathrm{~d}$ & $20.61 C$ & $25.09 b c$ & $16.63 \mathrm{ef}$ & 20.86B \\
\hline & Mean & 27.69A & $22.53 B$ & & 24.31A & 21.53B & \\
\hline
\end{tabular}

Values are the means of three replicates. Values followed by the same letters within a column for each genus are not significantly different at the $1 \%$ level of probability according to Duncan's multiple range test

Table (3): Main effects of genotype, GABA treatment and their interactions on N, P, K and Ca of garlic

\begin{tabular}{|c|c|c|c|c|c|c|c|}
\hline \multirow{3}{*}{ Parameters } & \multirow{3}{*}{ GABA } & \multicolumn{3}{|c|}{ 2015-2016 } & \multicolumn{2}{|c|}{ 2016-2017 } & \multirow{3}{*}{ Mean } \\
\hline & & \multicolumn{2}{|c|}{ Genotype } & \multirow{2}{*}{ Mean } & \multicolumn{2}{|c|}{ Genotype } & \\
\hline & & Egaseed & Sids 40 & & Egaseed & Sids 40 & \\
\hline \multirow{5}{*}{ N (mg/g DW) } & $0 \mathrm{mM}$ & $26.76 b c$ & $14.60 d$ & $20.68 C$ & $20.46 \mathrm{~cd}$ & $21.23 \mathrm{~cd}$ & $20.84 C$ \\
\hline & $1 \mathrm{mM}$ & $44.46 \mathrm{a}$ & $31.64 b$ & 38.05A & $34.16 \mathrm{a}$ & $31.64 \mathrm{ab}$ & $32.90 \mathrm{~A}$ \\
\hline & $2 \mathrm{mM}$ & $43.10 \mathrm{a}$ & $23.52 \mathrm{c}$ & 33.31B & $30.80 \mathrm{ab}$ & $23.52 \mathrm{c}$ & 27.16B \\
\hline & $4 \mathrm{mM}$ & $21.18 \mathrm{c}$ & $25.40 \mathrm{c}$ & 23.29C & $26.88 b c$ & $15.55 \mathrm{~d}$ & $21.22 \mathrm{C}$ \\
\hline & Mean & $33.88 \mathrm{~A}$ & 23.79B & & 28.08 A & 22.98B & \\
\hline \multirow{5}{*}{ P (mg/g DW) } & $0 \mathrm{mM}$ & $7.51 \mathrm{abc}$ & $4.78 \mathrm{~d}$ & $6.14 B$ & $6.51 \mathrm{ab}$ & $5.28 b$ & 5.89B \\
\hline & $1 \mathrm{mM}$ & $9.87 \mathrm{a}$ & 7.39abcd & $8.64 \mathrm{~A}$ & $7.87 \mathrm{a}$ & $7.39 a$ & $7.63 \mathrm{~A}$ \\
\hline & $2 \mathrm{mM}$ & $8.81 \mathrm{ab}$ & 7.39abcd & $8.10 A$ & $6.81 \mathrm{ab}$ & $7.39 \mathrm{a}$ & 7.10AB \\
\hline & $4 \mathrm{mM}$ & $5.38 \mathrm{~cd}$ & $7.17 \mathrm{bcd}$ & $6.28 \mathrm{~B}$ & $6.67 \mathrm{ab}$ & $5.88 \mathrm{ab}$ & $6.28 \mathrm{~B}$ \\
\hline & Mean & $7.89 \mathrm{~A}$ & $6.88 \mathrm{~B}$ & & $6.96 \mathrm{~A}$ & $6.49 \mathrm{~A}$ & \\
\hline \multirow{5}{*}{ K (mg/g DW) } & $0 \mathrm{mM}$ & $18.86 \mathrm{bcd}$ & $16.68 \mathrm{~cd}$ & 17.77B & $16.46 \mathrm{~d}$ & $16.68 \mathrm{~cd}$ & $16.56 \mathrm{C}$ \\
\hline & $1 \mathrm{mM}$ & $24.46 \mathrm{a}$ & $20.54 b c$ & $22.50 \mathrm{~A}$ & $25.56 \mathrm{a}$ & $21.04 b$ & $23.30 \mathrm{~A}$ \\
\hline & $2 \mathrm{mM}$ & $21.21 \mathrm{ab}$ & $16.20 \mathrm{~d}$ & 18.71B & $19.31 b c$ & $16.08 \mathrm{~d}$ & 17.69BC \\
\hline & $4 \mathrm{mM}$ & $17.58 \mathrm{bcd}$ & $18.58 \mathrm{bcd}$ & 18.08B & $19.61 b$ & $19.20 b c$ & $19.40 \mathrm{~B}$ \\
\hline & Mean & $20.53 A$ & 17.99B & & $20.23 A$ & $18.25 B$ & \\
\hline \multirow{5}{*}{ Ca (mg/g DW) } & $0 \mathrm{mM}$ & $6.30 \mathrm{bc}$ & $5.20 \mathrm{c}$ & 5.75B & $6.20 \mathrm{~b}$ & $5.00 \mathrm{~b}$ & $5.60 \mathrm{~B}$ \\
\hline & $1 \mathrm{mM}$ & $9.30 \mathrm{a}$ & $5.00 \mathrm{c}$ & $7.15 \mathrm{AB}$ & $8.20 \mathrm{a}$ & $6.40 \mathrm{ab}$ & $7.30 \mathrm{~A}$ \\
\hline & $2 \mathrm{mM}$ & $8.00 \mathrm{ab}$ & $7.90 \mathrm{ab}$ & $7.95 \mathrm{~A}$ & $6.40 \mathrm{ab}$ & $5.00 \mathrm{~b}$ & $5.70 \mathrm{~B}$ \\
\hline & $4 \mathrm{mM}$ & $7.40 \mathrm{ab}$ & $5.00 \mathrm{c}$ & $6.20 \mathrm{~B}$ & $5.05 \mathrm{~b}$ & $5.00 \mathrm{~b}$ & $5.03 B$ \\
\hline & Mean & $7.75 \mathrm{~A}$ & $5.78 B$ & & $6.46 \mathrm{~A}$ & $5.35 \mathrm{~B}$ & \\
\hline
\end{tabular}




\section{DISCUSSION}

The result of the current research undoubtedly reported that the foliar supplementation of GABA significantly enhanced vegetative and yield parameters in the two garlic's genotypes compared to un-treated plants. GABA treatments improved plant height, fresh plant weight, bulb weight and total yield per Feddan (Table 1). These outcomes compatible with the findings of Li et al. (2016b), who found that exogenous supplementation of GABA significantly enhanced the vegetative growth; shoot fresh weight and seedlings length in three maize cultivars. Also, Kathiresan et al. (1998) found that the GABA supplementation improved the stem elongation in Stellaria longipes. There are several scientific theories that explain GABA's mechanism in improving the plant growth and alleviation of the negative effects resulting from the abiotic stress. Previous studies illustrated that GABAinduced enhancement in several agricultural crops probably attributed to enhanced of water soluble cabohydartes, proline accumulation, total sugars content, chlorophyll content, phenolic substances, photosynthetic activity, antioxidant enzyme activities, relative water content and membrane stability (Krishnan et al., 2013; Vijayakumari and Puthur, 2015; Li et al., 2016; Li et al., 2017; Rezaei-Chiyaneh et al., 2018).

The improvement in plant growth and yield in the current study for GABA treatments in both tested garlic genotypes and seasons may have been associated with increasing the total chlorophyll content during vegetative growth. Our results clearly indicated that the GABA treatments: $1 \mathrm{mM}$ and $2 \mathrm{mM}$ improved the total chlorophyll content in treated plant compared to control and $4 \mathrm{mM}$ treated plants (Table 2). In this regard, exogenous GABA supplementation significantly increased chlorophyll parameters: $\mathrm{a}$ and $\mathrm{b}$ content by $6.2 \%$ and $19.2 \%$, respectively, and improved the structure and function of photosystem II in black cumin, muskmelon and pepper subjected to abiotic stress: water deficit, low light and salinityalkalinity (Xiang et al., 2016; Li et al., 2017; RezaeiChiyaneh et al., 2018). Moreover, GABA treatments reduced the chlorophyll degradation and improved the synthesis of carotenoids in black pepper and maize, thus improved photosynthetic system (Vijayakumari et al., 2015; Wang et al., 2017). In sum, the improvement in yield of garlic in current study might be attributed to the increase in the photosynthesis traits including cholorphyll content.

Phenolic compounds have important roles in the defense mechanism of higher plants through prevention lipids oxidation and eliminating the deleterious effects of reactive oxygen species (ROS) induced by abiotic stress (Pennycooke et al., 2005; Petridis et al., 2012). The result of our study clearly reported that GABA treatments significantly promoted the endogenous total phenols in garlic (Table 2). In the same context, exogenous GABA promoted the accumulation of phenolic substances in banana fruits, wheat and tomato plants under several types of abiotic stress (Wang et al., 2014; Farooq et al., 2017; Cekiç, 2018). Taken together, positive effect of GABA in increasing the agricultural productivity and mitigation of harmful effect of abiotic stresses probably due to accumulation of total phenols that improves antioxidant defense system, thus improving yield and efficiency of wateruse (Farooq et al., 2017). Phenylalanine ammonia lyase (PAL) is one of the essential enzymes associated with phenols biosynthesis. GABA treatment promoted PAL activity and recorded high content of total phenolics compared to untreated fruit (Wang et al., 2014). Our results suggest that GABA treatment might involve in acceleration of PAL activity in garlic bulbs and total phenolic content, leading to high total yield per Feddan in both garlic's genotypes.

The results proved that significant higher total sugars and TSS content connected with non-GABA treated plants (Table 2). These findings are not in harmony with the outcomes of Vijayakumari and Puthur (2015) and Rezaei-Chiyaneh et al. (2018), who found a positive correlation between GABA application and higher contacting of total sugars in black cumin and black paper plants, respectively. However, this result might be referred to increasing the vegetative growth and bulb size. It is obvious from the result of this study that GABA has a positive effect on elements content including N, P, K and Ca (Table 3). The highest mineral content: N, P, K and $\mathrm{Ca}$ was achieved in GABA treated plants that were sprayed with 1 and $2 \mathrm{mM}$ GABA in both genotypes and growing seasons. Further increase of GABA to $4 \mathrm{mM}$ did not increase the previous mentioned parameters. This novel result shows that GABA has supportive effect on the mineral composition of garlic bulb. Subsequently, GABA can increase garlic productivity through enhancing elements absorption from the soil, which can reduce the amount of the applied fertilizers. However, further studies are required to study effect of GABA on translocation of the macro elements such as $\mathrm{N}, \mathrm{P}$ and $\mathrm{K}$.

Generally, GABA treatments improved all studies traits, except SSC and total sugars in the current study (Table 1, 2 and 3). However, this improvement in growth and yield parameters in two garlic genotypes is dose-dependent. Where, the highest vegetative growth (plant height and plant fresh weight), bulb traits (bulb weight, bulbing ratio) yield, mineral content $(\mathrm{N}, \mathrm{P}, \mathrm{K}$, and $\mathrm{Ca}$ ) and organic content (total chlorophyll and total phenols) were achieved in GABA treated plants that were sprayed with 1 and $2 \mathrm{mM} \mathrm{GABA}$. Interestingly, increase of GABA to $4 \mathrm{mM}$ tended to decrease or does not improve the previous mentioned parameters. Several recent researches declared that low concentrations of GABA were more effective in improving plant growth than the high concentrations. In accordance with our findings, Farooq et al. (2017) reported that foliage applied GABA at $100 \mathrm{mg} / \mathrm{L}$ was more competent than another concentration $150 \mathrm{mg} / \mathrm{L}$ in alleviation of drought stress in two cultivars of bread wheat. Also, Krishnan et al. (2013) found that GABA supplementation at $50 \mathrm{mM}$ was reported to be more practical than $70 \mathrm{mM}$ in mitigation the damage in perennial ryegrass grown under water deficit condition. 
Also, Li et al. (2016a) reported that exogenous of GABA partially at $0.5 \mathrm{mM}$ enhanced photosynthetic trait and antioxidant enzyme actions in the $\mathrm{NaCl}-$ treated plants of wheat compared to other GABA treatment $(0.25 \mathrm{mM}$ and $1 \mathrm{mM})$. Taken together, the ideal GABA concentration significantly vary between the plants and it depends on the crop species itself and abiotic stress type and this point should be taken into account to get positive response on growth and productivity parameters.

\section{CONCLUSION}

The result of the current study reported that significant highest vegetative growth and yield parameters as well as chemical composition parameters: organic and non-organic were associated with Egaseed than Sids 40 over all GABA treatments. It also showed that GABA treatments gave higher values for all studies traits, except total sugars and SSC than un-treated plants. Generally, GABA treated-garlic plants with $1 \mathrm{mM}$ and $2 \mathrm{mM}$ gave the significant highest values for all studies traits, except total sugars and SSC compared to another GABA treatment (4 $\mathrm{mM})$. This result suggests that the positive GBAB effect is dose-dependent and it must be taken into account for the different agricultural crops in order to ensure high yield and productivity. The superior combination treatment for vegetative growth, yield and chemical composition parameters was Egaseed and foliar spray with GABA treatments at $1 \mathrm{mM}$. Based on the findings of this research, exogenous GABA application can increase the garlic growth and productivity under normal conditions through enhancing the mineral composition $(\mathrm{N}, \mathrm{P}, \mathrm{K}$ and $\mathrm{Ca}$ ) and organic compounds (total phenols and total chlorophyll).

\section{REFERENCES}

Çekiç, F. Ö. (2018). Exogenous GABA stimulates endogenous GABA and phenolic acid contents in tomato plants under salt stress. Celal Bayar Üniversitesi Fen Bilimleri Dergisi, 14(1): 61-64.

Chen, S., X. Shen, S. Cheng, P. Li, J. Du, Y. Chang and H. Meng (2013). Evaluation of garlic cultivars for polyphenolic content and antioxidant properties. PLoS One, 8(11): e79730.

Dubois, M. K. A., J. K. Hamilton, P. A. Rebers and F. Smith (1956) Colorimetric method for determination of sugars and related substances. Anal. Chem., 28: 350-356.

FAO (Food and Agriculture Organization of the United Nations), (2016) Retrieved January (2018) from the FAOSTAT on the world Wide. http://www.fao.org/faostat/en/\#data/QC

Farooq, M., A. Nawaz, M. A. M. Chaudhry, R. Indrasti and A. Rehman (2017). Improving resistance against terminal drought in bread wheat by exogenous application of proline and gamma-aminobutyric acid. Journal of
Agronomy and Crop Science, 203(6): 464472.

Ford, Y. Y., R. G. Ratcllffe and R. J. Robins (1996). Phytohormone-induced GABA production in transformed root cultures of Datura stramonium: an in vivo $15 \mathrm{~N}$ NMR study. Journal of experimental botany, 47(6): 811-818.

Gao, H., Q. Zeng, Z. Ren, P. Li and X. Xu (2018). Effect of exogenous $\gamma$-aminobutyric acid treatment on the enzymatic browning of fresh-cut potato during storage. Journal of food science and technology, 55(12): 50355044.

Hijaz, F., Y. Nehela and N. Killiny (2018). Application of gamma-aminobutyric acid increased the level of phytohormones in Citrus sinensis. Planta, 248(4): 909-918.

Oh, C. H. and S. H. Oh (2004). Effects of germinated brown rice extracts with enhanced levels of GABA on cancer cell proliferation and apoptosis. Journal of medicinal food, 7(1): 19-23.

Jackosn, M. L. (1973). Soil Chemical Analysis Prentice Halla of India Private Limited. New Delhi, Indian.

Kathiresan, A., J. Miranda, C. C. Chinnappa and D. M. Reid (1998). $\gamma$-aminobutyric acid promotes stem elongation in Stellaria longipes: The role of ethylene. Plant growth regulation, 26(2): 131-137.

Krishnan, S., K. Laskowski, V. Shukla and E. B. Merewitz (2013). Mitigation of drought stress damage by exogenous application of a non-protein amino acid $\gamma$-aminobutyric acid on perennial ryegrass. Journal of the American Society for Horticultural Science, 138(5): 358-366.

Kumar, R., S. Chhatwal, S. Arora, S. Sharma, J. Singh, N. Singh and A. Khurana (2013). Antihyperglycemic, antihyperlipidemic, antiinflammatory and adenosine deaminaselowering effects of garlic in patients with type 2 diabetes mellitus with obesity. Diabetes, metabolic syndrome and obesity: targets and therapy, 6: 49.

Ling, E. R. (1963). Determination of total nitrogen by semimicrokjeldahl method. Dairy Chem. 11: 23-84.

Li, M. F., S. J. Guo, X. H. Yang, Q. W. Meng and X. J. Wei (2016a). Exogenous gammaaminobutyric acid increases salt tolerance of wheat by improving photosynthesis and enhancing activities of antioxidant enzymes. Biologia plantarum, 60(1): 123131.

Li, W., J. Liu, U. Ashraf, G. Li, Y. Li, W. Lu and J. $\mathrm{Hu}$ (2016b). Exogenous $\gamma$-aminobutyric acid (GABA) application improved early growth, net photosynthesis, and associated physiobiochemical events in maize. Frontiers in plant science, 7: 919. 
Li, Y., Y. Fan, Y. Ma, Z. Zhang, H. Yue, L. Wang and Y. Jiao (2017). Effects of exogenous $\gamma$ aminobutyric acid (GABA) on photosynthesis and antioxidant system in pepper (Capsicum annuum L.) seedlings under low light stress. Journal of Plant Growth Regulation, 36(2): 436-449.

Li, Z., Y. Peng and B. Huang (2018). Alteration of Transcripts of Stress-Protective Genes and Transcriptional Factors by $\gamma$-Aminobutyric Acid (GABA) Associated with Improved Heat and Drought Tolerance in Creeping Bentgrass (Agrostis stolonifera). International journal of molecular sciences, 19(6): 1623.

Mann, L. K. (1952). Anatomy of the garlic bulb and factors affecting bulb development. Hilgardia 21: 195-231.

Martins, N., S. Petropoulos and I. C. Ferreira (2016). Chemical composition and bioactive compounds of garlic (Allium sativum L.) as affected by pre-and post-harvest conditions: A review. Food chemistry, 21: 41-50.

Mazumdar, B. C. and K. Majumder (2003). Methods on physico-chemical analysis of fruits. Daya publishing house.

Mirzaei Mashhoud, M., M. Aelaei and S. N. Mortazavi (2015, May). $\gamma$-Aminobutyric acid (GABA) treatment improved postharvest indices and vase-life of' Red Naomi'rose cut flowers. In III International Conference on Quality Management in Supply Chains of Ornamentals 1131 (pp. 33-40).

Nonaka, S., C. Arai, M. Takayama, C. Matsukura and H. Ezura (2017). Efficient increase of $\square$ aminobutyric acid (GABA) content in tomato fruits by targeted mutagenesis. Scientific reports, 7(1): 7057.

Page, A.L., R. H. Miller and D. R. Keeney (1982). Methods of Soil Analysis. Part 2: Chemical and Microbiological Properties. ASA, Madison, WI.

Pennycooke, J. C., S. Cox and C. Stushnoff (2005). Relationship of cold acclimation, total phenolic content and antioxidant capacity with chilling tolerance in petunia (Petunia $\times$ hybrida). Environmental and Experimental Botany, 53(2): 225-232.

Petridis, A., I. Therios, G. Samouris and C. Tananaki (2012). Salinity-induced changes in phenolic compounds in leaves and roots of four olive cultivars (Olea europaea L.) and their relationship to antioxidant activity. Environmental and Experimental Botany, 79: 37-43.

Rezaei-Chiyaneh, E., S. M Seyyedi, E. Ebrahimian, S. S. Moghaddam and C. A. Damalas (2018). Exogenous application of gammaaminobutyric acid (GABA) alleviates the effect of water deficit stress in black cumin (Nigella sativa L.). Industrial Crops and Products, 112: 741-748.

Shang, H., S. Cao, Z. Yang, Y. Cai and Y. Zheng (2011). Effect of exogenous $\gamma$-aminobutyric acid treatment on proline accumulation and chilling injury in peach fruit after long-term cold storage. Journal of agricultural and food chemistry, 59(4): 1264-1268.

Shelp, B. J., G. G. Bozzo, C. P. Trobacher, G. Chiu, and V.S. Bajwa (2012). Strategies and tools for studying the metabolism and function of $\gamma$-aminobutyrate in plants. I. Pathway structure. Botany, 90(8): 651-668.

Sigel, E. and M. E. Steinmann (2012). Structure, function, and modulation of GABAA receptors. Journal of Biological Chemistry, 287(48), 40224-40231.

Vijayakumari, K. and J. T. Puthur (2016). $\gamma$ Aminobutyric acid (GABA) priming enhances the osmotic stress tolerance in Piper nigrum Linn. plants subjected to PEGinduced stress. Plant growth regulation, 78(1): 57-67.

Wang, X., B. Xie, W. An, J. Li, Z. Zhai and L. Duan (2009). Effects of exogenous GABA on yield, quality and high temperature tolerance of winter wheat at the anthesis stage. Journal of Triticeae Crops, 29(4): 623-626.

Wang, C., L. Fan, H. Gao, X. Wu, J. Li, G. Lv and B. Gong (2014). Polyamine biosynthesis and degradation are modulated by exogenous gamma-aminobutyric acid in root-zone hypoxia-stressed melon roots. Plant physiology and biochemistry, 82: 17-26.

Wang, Y., W. Gu, Y. Meng, T. Xie, L. Li, J. Li and S. Wei (2017). $\gamma$-Aminobutyric acid imparts partial protection from salt stress injury to maize seedlings by improving photosynthesis and up regulating osmoprotectants and antioxidants. Scientific reports, 7: 43609.

Xiang, L., L. Hu, W. Xu, A. Zhen, L. Zhang and X. Hu (2016). Exogenous $\gamma$-aminobutyric acid improves the structure and function of photosystem II in muskmelon seedlings exposed to salinity-alkalinity stress. PloS one, 11(10), e0164847.

Yang, R., Q. Guo, and Z. Gu (2013). GABA shunt and polyamine degradation pathway on $\gamma$ aminobutyric acid accumulation in germinating fava bean (Vicia faba L.) under hypoxia. Food chemistry, 136(1): 152-159.

Yun, H. M., J. O. Ban, K. R. Park, C. K. Lee, H. S. Jeong, S. B. Han and J. T. Hong (2014). Potential therapeutic effects of functionally active compounds isolated from garlic. Pharmacology and therapeutics, 142(2): 183-195. 


\section{إستجابه نمو ومحصول أصناف الثوم للرش الورقي بحامض جاما امينو بيوتريك

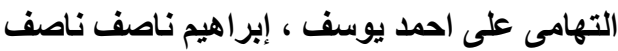

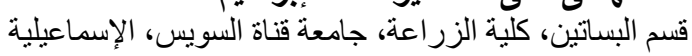

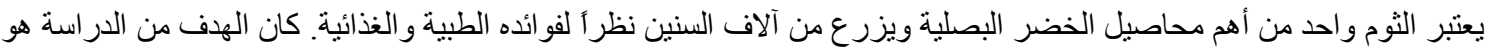

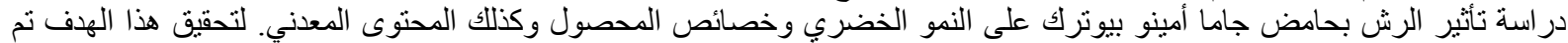

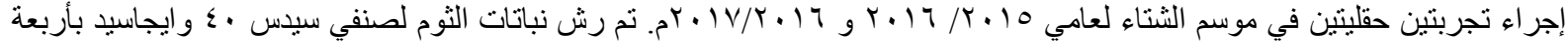

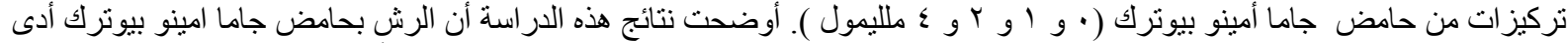

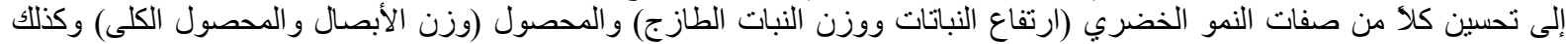

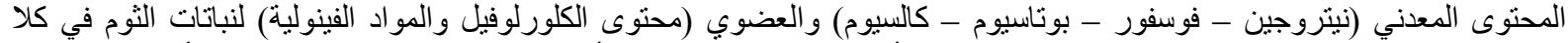

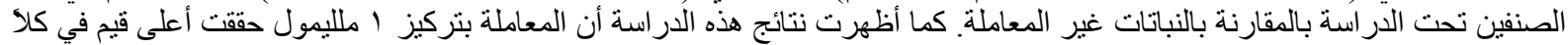

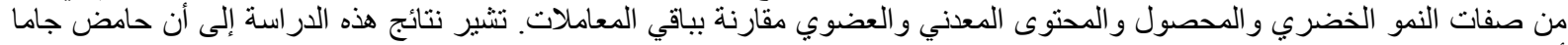

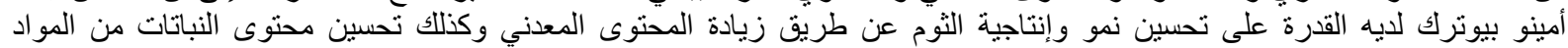

